\title{
Design and testing of a steel stud wall system for blast mitigation
}

\author{
L. K. Stewart ${ }^{1}$, A. Freidenberg ${ }^{2}$ \& G. Hegemier ${ }^{3}$ \\ ${ }^{1}$ School of Civil and Environmental Engineering, \\ Georgia Institute of Technology, USA \\ ${ }^{2}$ Civil and Environmental Engineering Department, \\ Manhattan College, USA \\ ${ }^{3}$ Department of Structural Engineering, University of California, \\ San Diego, USA
}

\begin{abstract}
With the requirements for blast mitigation design becoming more prevalent, the necessity for constructible, cost effective mitigation strategies becomes increasingly important. To feasibly implement the blast mitigation systems for more general use, the designs must be relatively inexpensive as compared to standard construction and consist of specifications that a typical contractor can easily implement. A steel stud wall system that uses a patented composite system of cement board with sheet steel was developed and, along with specific connection details, shown to be an effective blast mitigation strategy.

Multiple, full-scale steel stud walls were tested for blast performance at the University of California, San Diego Blast Simulation Facility where explosivetype loads are generated using ultra-fast hydraulic actuators. The tests were used to optimize the various wall designs for typical low-level US blast requirements. This paper serves to highlight the testing strategy and major findings of the steel stud system behavior.
\end{abstract}

Keywords: blast, steel stud walls, blast panels, connections.

\section{Introduction}

Design requirements for non-load bearing walls have become standard in many blast guidelines in the US and abroad. Because of this, decades of research has been done to develop and analyze mitigation strategies for steel studs and their 
connections to resist various levels of threats [1-3]. Often times, especially for the higher level threats, the designs are heavy and hard to construct in the field. This paper presents the design and testing of a relatively low-cost, easily constructible blast mitigation system to meet US blast guidelines for pressure and impulses from threats such as those seen in far-field explosive scenarios.

\section{Simulated blast loads}

\subsection{The Blast Simulator}

The Blast Simulator, shown in Figure 1 was initially developed by MTS Corporation for use at the University of California San Diego in 2005 as an alternative experimental approach to field testing [4]. To reproduce the types of pressures and impulses created by explosions, the Blast Simulator system uses a combination of pressurized nitrogen and hydraulic oil in conjunction with unique actuator systems known as Blast Generators (BGs). The generators operate through interactions between accumulated pressure, hydraulic oil, and a piston assembly which is rapidly forced out of the generator. Pressure transducers and high-precision poppet valves are used to monitor and control the flow of oil and transfer of pressure to produce a very specific motion of the piston. This motion is programmed by specifying various input parameters including pressure levels and the starting position of the piston before the test.

Mounted to the piston is a custom aluminum or steel plate. Because the size of this mass can be adjusted, the total weight being applied to the specimen and, thus, the incoming energy can be easily modified to impart different loads. Attached to the mass is a specially designed urethane pad with a specific pyramidal geometry. The pyramids extending from the front face were designed specifically to reproduce the types of loading durations experienced during blast events. An examination of the adiprene material which comprises the pad is provided in [5]. The combination of the metal plate, programmer, and any other attachments will collectively be referred to as the "impacting mass" for the purposes of this paper. Also, the velocity at which the impacting mass collides with the test article will be known as the "impact velocity." The desired impact velocity programmed for the test, which is typically not identical to the true impact velocity but very close, will be known as the "target impact velocity" in subsequent sections.

\subsection{Measurement and methodology}

Various instrumentation is used throughout the BG to ensure proper setup and function. Multiple pressure transducers in each BG provide readings of all the actuator pressures to allow precise setup and to measure actuator forces during impact. Each actuator's position is measured using externally mounted magnetostrictive position transducers. The differentiated stroke transducer provides an accurate measure of impact velocity. Accelerometers are placed on 


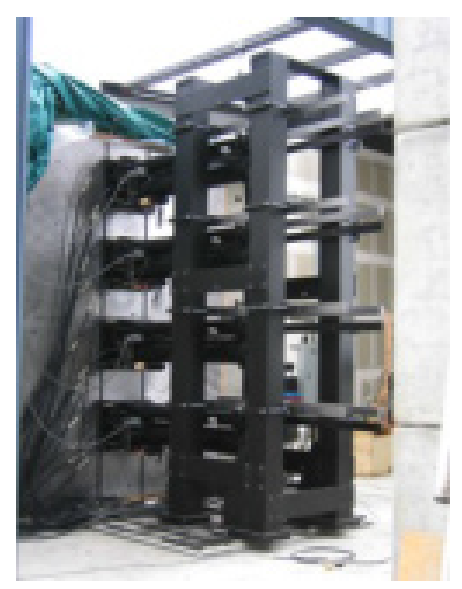

Figure 1: Blast Simulator located at University of California, San Diego.

the back (non-impact) side of the impacting mass and specimen to record impact data for calculating force and impulse.

Force-time histories are primarily derived from acceleration data, $a(t)$, from accelerometers that are located on the back (non-impact) side of the impact masses. In the case where the impacting mass remains attached to the piston rod, the hydraulics are connected to the impact mass throughout the collision. At a specified time, the hydraulics begin to pull back on the impact mass near the end of the collision. This pulling back prevents a "double-hit" and tailors the impact so that the loading is blast-like in duration and shape. The formula for the force on the impact mass is therefore given by eqn (1), where $F(t)_{\text {hydraulic }}$ is the hydraulic force, $F(t)_{n e t}$ is the force on the impacting mass and $F(t)_{\text {specimen }}$ is the force applied to the specimen. An example of a pressure-time history using this method compared to field testing [6] is given in Figure 2.

$$
F(t)_{n e t}=m a(t)=F(t)_{\text {specimen }}-F(t)_{\text {hydraulic }}
$$

\section{Blast Simulator experiments}

The Blast Simulator tests were used to optimize and design an efficient system for blast loads under $690 \mathrm{kPa}-\mathrm{ms}$ (100 psi-ms) impulse and $69 \mathrm{kPa}(10 \mathrm{psi})$ peak pressure. The tests, conducted in late 2010, included a variety of options and configurations, varying in effectiveness, in the process of the optimization.

\subsection{Test specimens}

An example of one of the test specimen included in the series is shown in Figure 3. The specimens consisted of $15.24 \mathrm{~cm} \times 4.13 \mathrm{~cm}(6$ in $\times 1.625 \mathrm{in})$ steel studs 

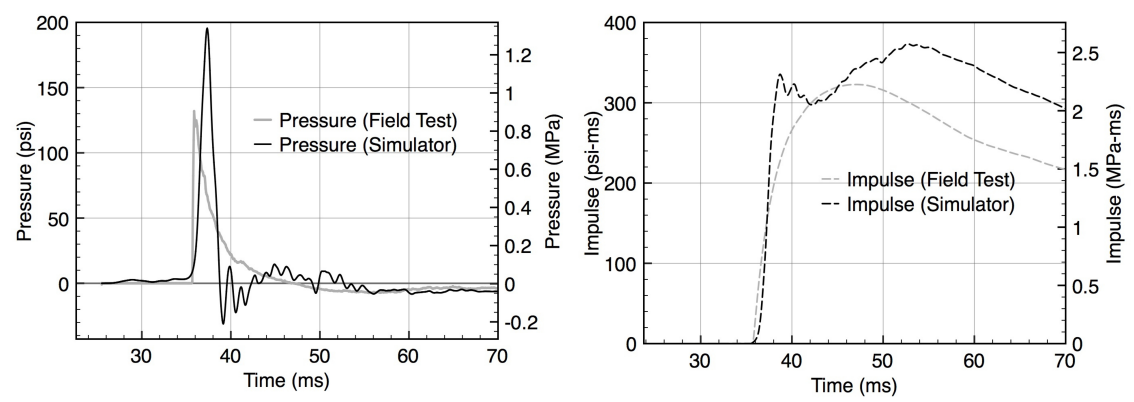

Figure 2: Example pressure-time history from Blast Simulator.

retrofitted with Sure-Board 200B ${ }^{\circledR}$ composite panels, which combines steel with gypsum-based products. For the tests conducted, the panels consisted of $1.589 \mathrm{~cm}$ (0.625 in) USG DuroRock cement board laminated to 14 gage $(0.18 \mathrm{~cm} / 0.071 \mathrm{in})$ steel on the loaded (outside) panel and $1.589 \mathrm{~cm}(0.625 \mathrm{in})$ USG Type-X Gypsum Board was used with 22 gage $(0.069 / 0.027$ in) steel on the non-loaded (inside) panel. On the outside, the Sure-Board $200 \mathrm{~B}^{\circledR}$ product was attached to the steel studs using a combination of Tyrex and Simpson Quick Drive \#14, $4.445 \mathrm{~cm}$ $(1.75 \mathrm{in})$ screws spaced at $10.16 \mathrm{~cm}$ (4 in) along the edge and at $15.24 \mathrm{~cm}(6 \mathrm{in})$ the field area. For the inside panel, a combination of Grabber and Hilti $4.13 \mathrm{~cm}$ $(1.625 \mathrm{in})$ screws were used at spacing of $15.24 \mathrm{~cm}(6 \mathrm{in})$ for attachment to the steel studs.

The experimental program consisted of four main bottom connection details (Figure 4) used during the optimization process: connection angle, now-patented Blast-clip ${ }^{\circledR}$, bearing washer, and Blast-washer ${ }^{\circledR}$. Throughout the test series, these details were combined, optimized and adjusted. Not all details provided suitable results for blast mitigation Additional details on these findings are discussed in Section 4. The angle detail consisted of a $15.2 \mathrm{~cm} \times 15.2 \mathrm{~cm} \times 0.95 \mathrm{~cm}(6$ in $\times$ 6 in $\times .375$ in) steel angle bolted to the footer using Hilti Wedge Anchors and
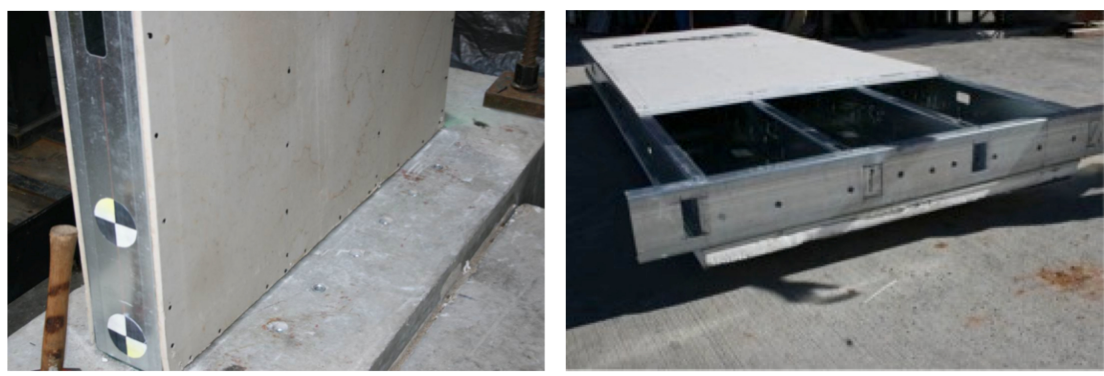

Figure 3: Test specimen. 
$7.6 \mathrm{~cm}$ ( 3 in) long, $1.6 \mathrm{~cm}$ ( $5 / 8 \mathrm{in})$ diameter bolts. The square bearing washers were $10.2 \mathrm{~cm}(4 \mathrm{in})$ in length and used the $1.6 \mathrm{~cm}(5 / 8 \mathrm{in})$ diameter bolts with nut. The Blast-washer ${ }^{\circledR}$ is custom to the track size and is attached to the footer with a $1.6 \mathrm{~cm}\left(5 / 8\right.$ in) diameter bolt. The Blast-clip ${ }^{\circledR}$ connects the track to the stud with an L-shaped bracket attached with screws.

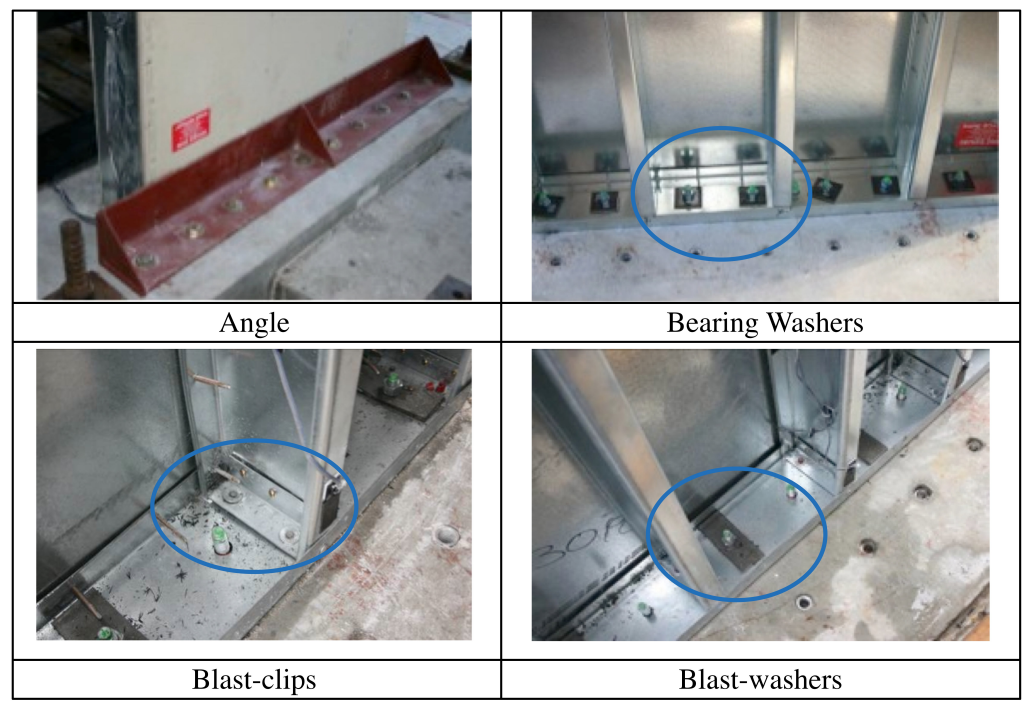

Figure 4: Bottom connection details.

\subsection{Test setup}

The test setup, shown in Figure 5, was designed to simulate a typical one story steel stud wall retrofit. The $3.28 \mathrm{~m}$ (10 ft-6 in) stud wall was placed on a $0.61 \mathrm{~m}$ ( $2 \mathrm{ft}$ ) footer and reacted against a $15.24 \mathrm{~cm}$ ( 6 in) concrete slab header held up by steel angles and steel tube supports. The top of the specimen was connected to the header using $25.4 \mathrm{~cm}$ ( $10 \mathrm{in}$ long), $1.59 \mathrm{~cm}$ ( $5 / 8 \mathrm{in})$ high strength steel bolts. The angles were screwed into the specimen studs and rotations at the top of the wall were partially suppressed.

\subsection{Test matrix}

The experimental program consisted of ten full-scale, wall system tests. The test matrix describing stud spacing, connection details and target velocity is given in Table 1. It is noted that some specimen were tested more than once and Test 9 included an exterior insulating finishing system (EIFS). 

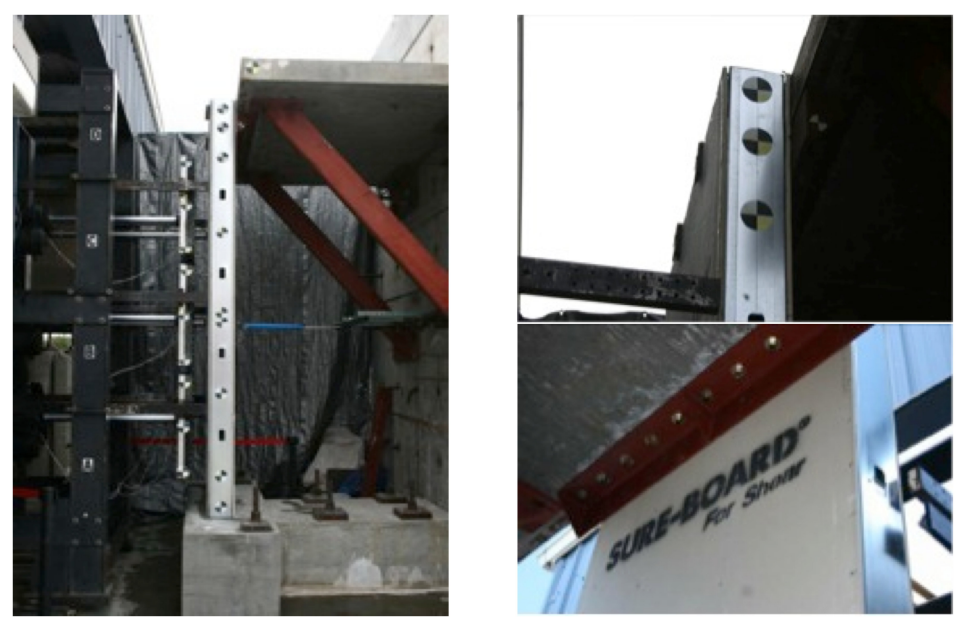

Figure 5: Test setup (left) and upper connection (right).

Table 1: Test matrix.

\begin{tabular}{|c|c|c|c|c|}
\hline Test & Spacing & Bottom connection & Top connection & Target velocity \\
\hline 1 & $\begin{array}{l}40.6 \mathrm{~cm} \\
(16 \mathrm{in})\end{array}$ & Angle & $\begin{array}{c}\text { Angle and } \\
\text { L-Brackets }\end{array}$ & $\begin{array}{c}4 \mathrm{~m} / \mathrm{s} \\
(13.1 \mathrm{ft} / \mathrm{s})\end{array}$ \\
\hline 2 & $\begin{array}{l}40.6 \mathrm{~cm} \\
(16 \mathrm{in})\end{array}$ & Angle & $\begin{array}{l}\text { Angle and } \\
\text { L-Brackets }\end{array}$ & $\begin{array}{c}6 \mathrm{~m} / \mathrm{s} \\
(19.7 \mathrm{ft} / \mathrm{s})\end{array}$ \\
\hline 3 & $\begin{array}{l}40.6 \mathrm{~cm} \\
(16 \mathrm{in})\end{array}$ & Angle & $\begin{array}{l}\text { Angle and } \\
\text { L-Brackets }\end{array}$ & $\begin{array}{c}10 \mathrm{~m} / \mathrm{s} \\
(32.8 \mathrm{ft} / \mathrm{s})\end{array}$ \\
\hline 4 & $\begin{array}{r}40.6 \mathrm{~cm} \\
(16 \mathrm{in})\end{array}$ & Angle & $\begin{array}{l}\text { Angle and } \\
\text { L-Brackets }\end{array}$ & $\begin{array}{c}15 \mathrm{~m} / \mathrm{s} \\
(49.2 \mathrm{ft} / \mathrm{s})\end{array}$ \\
\hline 5 & $\begin{array}{l}40.6 \mathrm{~cm} \\
(16 \mathrm{in})\end{array}$ & Angle & $\begin{array}{l}\text { Angle and } \\
\text { L-Brackets }\end{array}$ & $\begin{array}{c}20 \mathrm{~m} / \mathrm{s} \\
(65.6 \mathrm{ft} / \mathrm{s})\end{array}$ \\
\hline 6 & $\begin{array}{l}30.5 \mathrm{~cm} \\
(12 \mathrm{in})\end{array}$ & $\begin{array}{c}\text { Angle and } \\
\text { Bearing Washers }\end{array}$ & $\begin{array}{c}\text { Angle and } \\
\text { Extended L-Brackets }\end{array}$ & $\begin{array}{c}10 \mathrm{~m} / \mathrm{s} \\
(32.8 \mathrm{ft} / \mathrm{s})\end{array}$ \\
\hline 7 & $\begin{array}{r}30.5 \mathrm{~cm} \\
(12 \mathrm{in}) \\
\end{array}$ & Bearing Washers & $\begin{array}{c}\text { Angle and } \\
\text { Extended L-Brackets }\end{array}$ & $\begin{array}{c}15 \mathrm{~m} / \mathrm{s} \\
(49.2 \mathrm{ft} / \mathrm{s}) \\
\end{array}$ \\
\hline 8 & $\begin{array}{r}40.6 \mathrm{~cm} \\
(16 \mathrm{in})\end{array}$ & $\begin{array}{l}\text { Bearing Washers and } \\
\text { Blast-clips }\end{array}$ & $\begin{array}{c}\text { Angle and } \\
\text { Extended L-Brackets }\end{array}$ & $\begin{array}{c}15 \mathrm{~m} / \mathrm{s} \\
(49.2 \mathrm{ft} / \mathrm{s})\end{array}$ \\
\hline $\begin{array}{c}9 \\
\text { EIFS }\end{array}$ & $\begin{array}{l}40.6 \mathrm{~cm} \\
(16 \mathrm{in})\end{array}$ & $\begin{array}{l}\text { Bearing Washers and } \\
\text { Blast-clips }\end{array}$ & $\begin{array}{c}\text { Angle and } \\
\text { Extended L-Brackets }\end{array}$ & $\begin{array}{c}15 \mathrm{~m} / \mathrm{s} \\
(49.2 \mathrm{ft} / \mathrm{s})\end{array}$ \\
\hline 10 & $\begin{array}{l}30.5 \mathrm{~cm} \\
(12 \mathrm{in})\end{array}$ & $\begin{array}{c}\text { Blast-washers and } \\
\text { Blast-clips }\end{array}$ & $\begin{array}{c}\text { Angle and } \\
\text { Extended L-Brackets }\end{array}$ & $\begin{array}{c}17 \mathrm{~m} / \mathrm{s} \\
(55.8 \mathrm{ft} / \mathrm{s})\end{array}$ \\
\hline
\end{tabular}

\section{Results}

A summary of the results for all on the ten tests is given in Table 2. Results from a representative test is given in Section 4.1. Additionally, Section 4.2 provides comparisons between the tests highlighting effective blast mitigating components and details that are less effective. 
Table 2: Test results summary.

\begin{tabular}{|c|c|c|c|}
\hline Test & Impact velocity & Impulse & Displacement \\
\hline 1 & $5.6 \mathrm{~m} / \mathrm{s}$ & $\begin{array}{c}264 \mathrm{kPa}-\mathrm{ms} \\
(38.4 \mathrm{psi}-\mathrm{ms})\end{array}$ & $\begin{array}{c}2.2 \mathrm{~cm} \\
(0.87 \mathrm{in})\end{array}$ \\
\hline 2 & $6.3 \mathrm{~m} / \mathrm{s}$ & $340 \mathrm{kPa}-\mathrm{ms}$ & $2.87 \mathrm{~cm}$ \\
& $(20.7 \mathrm{ft} / \mathrm{s})$ & $(49.4 \mathrm{psi}-\mathrm{ms})$ & $(1.13 \mathrm{in})$ \\
\hline 3 & $8.3 \mathrm{~m} / \mathrm{s}$ & $271 \mathrm{kPa}-\mathrm{ms}$ & $2.90 \mathrm{~cm}$ \\
& $(27.2 \mathrm{ft} / \mathrm{s})$ & $(39.3 \mathrm{psi}-\mathrm{ms})$ & $(1.14 \mathrm{in})$ \\
\hline 4 & $12.8 \mathrm{~m} / \mathrm{s}$ & Not Available & $2.97 \mathrm{~cm}$ \\
& $(42.0 \mathrm{ft} / \mathrm{s})$ & Not Available & $(1.17 \mathrm{in})$ \\
\hline 5 & $19.1 \mathrm{~m} / \mathrm{s}$ & $700 \mathrm{kPa}-\mathrm{ms}$ & $11.18 \mathrm{~cm}$ \\
& $(62.7 \mathrm{ft} / \mathrm{s})$ & $(101.5 \mathrm{psi}-\mathrm{ms})$ & $(4.40 \mathrm{in})$ \\
\hline 6 & $10.7 \mathrm{~m} / \mathrm{s}$ & $437 \mathrm{kPa}-\mathrm{ms}$ & $2.34 \mathrm{~cm}$ \\
& $(35.1 \mathrm{ft} / \mathrm{s})$ & $(63.4 \mathrm{psi}-\mathrm{ms})$ & $(0.92 \mathrm{in})$ \\
\hline 7 & $14.6 \mathrm{~m} / \mathrm{s}$ & $837 \mathrm{kPa}-\mathrm{ms}$ & $6.78 \mathrm{~cm}$ \\
& $(47.9 \mathrm{ft} / \mathrm{s})$ & $(121.4 \mathrm{psi}-\mathrm{ms})$ & $(2.67 \mathrm{in})$ \\
\hline 8 & $14.4 \mathrm{~m} / \mathrm{s}$ & $527 \mathrm{kPa}-\mathrm{ms}$ & $6.62 \mathrm{~cm}$ \\
& $(47.2 \mathrm{ft} / \mathrm{s})$ & $(76 \mathrm{psi}-\mathrm{ms})$ & $(2.61 \mathrm{in})$ \\
\hline 9 & $12.5 \mathrm{~m} / \mathrm{s}$ & $524 \mathrm{kPa}-\mathrm{ms}$ & $8.33 \mathrm{~cm}$ \\
& $(41.0 \mathrm{ft} / \mathrm{s})$ & $(76.0 \mathrm{psi}-\mathrm{ms})$ & $(3.28 \mathrm{in})$ \\
\hline 10 & $15.8 \mathrm{~m} / \mathrm{s}$ & $645 \mathrm{kPa}-\mathrm{ms}$ & $9.40 \mathrm{~cm}$ \\
& $(51.8 \mathrm{ft} / \mathrm{s})$ & $(93.5 \mathrm{psi}-\mathrm{ms})$ & $(3.70 \mathrm{in})$ \\
\hline & & & \\
& & & $(18)$. \\
\hline
\end{tabular}

\subsection{Representative test results}

This section provides the results from Test 10, a representative wall experiment. Test 10 included the custom Blast-washers and Blast-clips at the bottom connection and an angle support at the top. The target impact velocity was $17 \mathrm{~m} / \mathrm{s}$ $(55.8 \mathrm{ft} / \mathrm{s})$ and the recorded impact velocity was $15.8 \mathrm{~m} / \mathrm{s}(51.8 \mathrm{ft} / \mathrm{s})$.

Figure 6 shows the progression of damage of the wall at various times after impact recorded with Phantom cameras at 5,000 frames per second. A hinge formed at the utility hole closest to midspan. A closer view of the hinge is shown in Figure 7.

Displacements were measured with the high-speed camera footage and the tracking software, TEMA. A redundant set of measurements were taken at the midspan using an LVDT. The two measurements were averaged at the midspan and it was determined that the maximum displacement of the wall was $14.5 \mathrm{~cm}$ (5.7 in) and the residual was $9.4 \mathrm{~cm}$ (3.7 in).

\subsection{Comparisons}

This section provides two of the many comparisons made during the design and optimization process regarding the connection detailing at the bottom.

\subsubsection{Connection type}

Test 4 and Test 8 both included systems with studs spaced at $40.6 \mathrm{~cm}$ (16 in) on center. The tests both had a target impact velocity of $15 \mathrm{~m} / \mathrm{s}(49.2 \mathrm{ft} / \mathrm{s})$. In the case 
of Test 4, the bottom connection consisted of the bottom angle. In the case of Test 8, the bottom connection consisted of the bearing washers and Blast-clips. Post-Test photos from Test 4 are given in Figure 8. The residual displacement found in this test was $3.0 \mathrm{~cm}$ (1.2 in). The bottom connection showed little damage further than the buckling of the web section of the stud from the contact with the angle. This method proved to be effective for these relatively low pressures and impulses. However, from a cost and constructibility standpoint, the addition of a large angle in the floor space of the room is not ideal. Because of this, an additional design was considered.

The second design, Test 8 , consisted of bearing washers and Blast-clips. The results from these tests are shown in Figure 9. The displacement in this test was measured to be $6.6 \mathrm{~cm}$ (2.6in), which is greater than the displacements with the angle due to the connection behaving more like a hinge. This design, however, is much more cost-effective and architecturally pleasing because it does not interfere with the floor space. The design did not pose any major issues and if it meets the governing displacement requirement, is suitable and desired for the relevant threats.
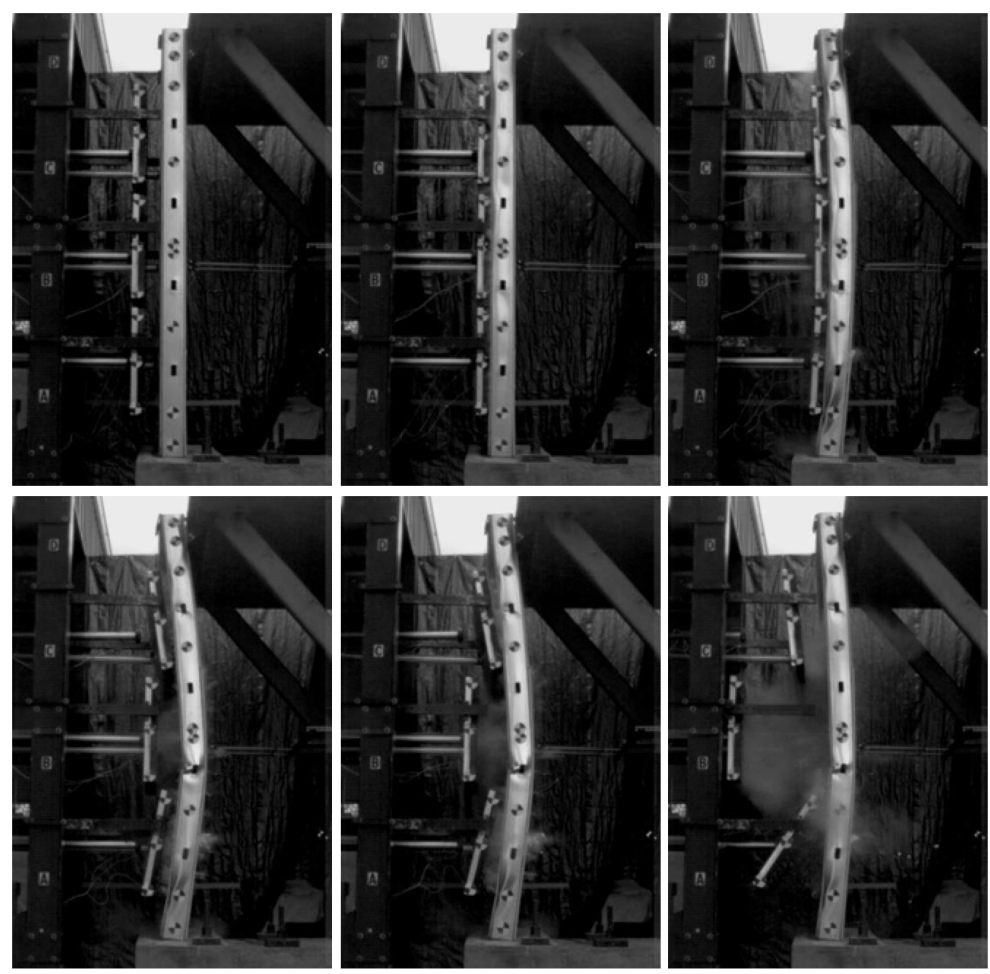

Figure 6: Progression of damage. 


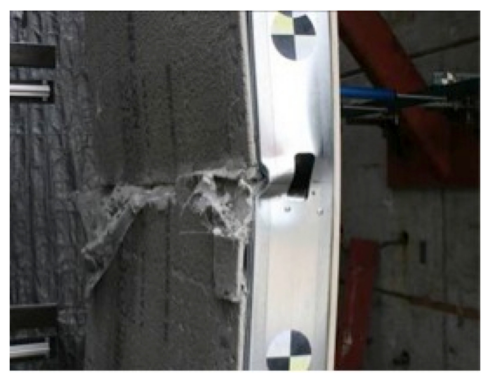

Figure 7: Hinge formed at utility hole.
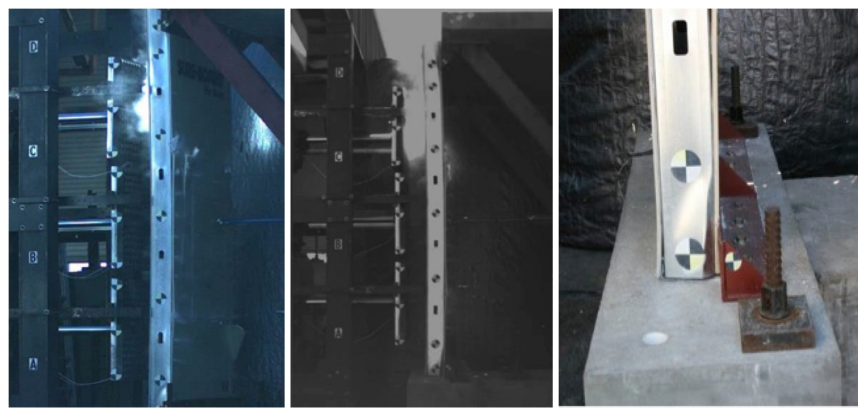

Figure 8: Test 4 post test photos.
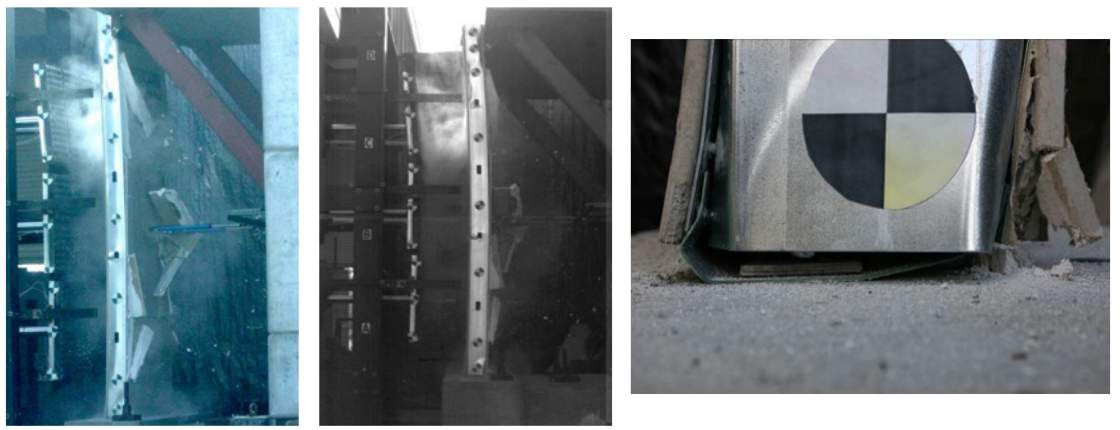

Figure 9: Test 8 post test photos.

\subsubsection{Washer type}

Tests 8 and 10 provide a good comparison for the type of washers being considered. Test 8 utilized the smaller bearing washers while Test 10 utilized the custom Blast-washers. Figure 10 provides post test photos comparing the two connection behaviors. The damage seen with the bearing washers is much more 
prominent than the custom, larger Blast-washers. The bearing washers allowed for excess rotation which caused pull out of the screws holding the track to the stud. The additional length of washers prevented this response and produced a more desirable response.
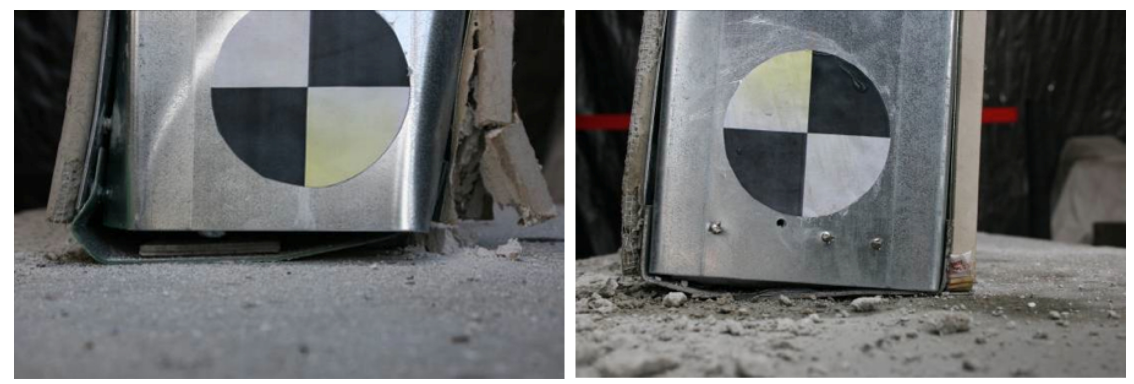

Figure 10: Comparison of washer behavior.

\section{Field tests}

Field testing of similar wall systems were conducted in 2012 at Tyndall Air Force Base. Results from those tests are given in [7] and were used to validate the Blast Simulator's utility as an effective way to test steel stud wall systems [6].

\section{Conclusions}

Through the testing of multiple steel stud wall systems with various spacing and connection configurations, the UCSD Blast Simulator was shown to be an effective method for applying simulated blast load on steel stud wall systems. The Blast Simulator experiments provided quantitative data and observations that were used to optimize and develop a low-cost, easily constructible stud wall system using composite panels for blast mitigation for relevant threat levels.

\section{Acknowledgements}

The authors would like to thank Mr. Tyler Elliot for constructing the specimens. This research was supported by Protective Technologies Group and Sure-Board.

\section{References}

[1] Salim, H. \& Townsend, P., Explosion-resistant steel stud wall system. Structures 2004: Building on the Past, Securing the Future, ASCE, 2004. 
[2] DiPaolo, B. \& Woodson, S., An overview of research at ERDC on steel stud exterior wall systems subjected to severe blast loads. Structures Congress 2006: Structural Engineering and Public Safety, 2006.

[3] Stewart, L., Morrill, K. \& Natesaiyer, K., Development of high performance concrete panels for curtainwall systems. Structures Congress 2012, ASCE.

[4] Gram, M., Clark, A.J., Hegemier, G.A. \& Seible, F., Laboratory simulation of blast loading on build and bridge structures. WIT Transactions on the The Built Environment, 87, pp. 33-44, 2006.

[5] Freidenberg, A., Lee, C., Durant, B., Nesterenko, V.F., Stewart, L. \& Hegemier, G., Characterization of the blast simulator elastomer material using a pseudo-elastic rubber model. International Journal of Impact Engineering, 60, pp. 58-66, 2013.

[6] Freidenberg, A., Aviram, A., D.Whisler, Kim, H., Stewart, L. \& Hegemier, G., Demonstration of tailored impact to achieve blast-like loading. Submitted to International Journal of Impact Engineering, July 2013.

[7] Aviram, A., Mays, R. \& Hamburger, R., Enhanced blast-resistance of an innovative high strength steel wall system. SEAOC Proceedings, Santa Fe, NM, 2012 Structural Engineers Association of California Convention, 2012. 